\section{Resistance of Dry Bean and Snap Bean Cultivars to Root-knot Nematodes}

\author{
Sindynara Ferreira, Luiz Antonio A. Gomes, and Wilson Roberto Maluf ${ }^{1}$ \\ Universidade Federal de Lavras, Department de Agricultura, Campus \\ Universitario, Lavras, MG 37200-000, Brazil
}

\author{
Vicente Paulo Campos \\ Departamento de Fitopatologia, Universidade Federal de Lavras-UFLA, \\ 37200-000, Lavras, MG, Brazil
}

\begin{abstract}
José Luiz S. de Carvalho Filho and Daniela Costa Santos
Departamento de Agricultura, Universidade Federal de Lavras-UFLA, 37200-000, Lavras, MG, Brazil
\end{abstract}

Additional index words. Phaseolus vulgaris L., Meloidogyne spp., resistance, breeding

\begin{abstract}
This study assessed the reaction of dry bean and snap bean cultivars to infection by Meloidogyne incognita (races 1,3$)$ and by Meloidogyne javanica, two species of rootknot nematodes. Three independent experiments were done, one for each species or race of Meloidogyne, using randomized complete block designs with four replications (plots) and four plants per plot. A plot with the susceptible tomato cultivar Santa Clara was used in each block to determine the efficiency of the inoculum and to calculate the reproduction rate for each of the genotypes assessed. The bean cultivars Aporé and Talismã were highly resistant to Meloidogyne javanica, slightly resistant to Meloidogyne incognita race 1 , and moderately resistant and slightly resistant, respectively, to Meloidogyne incognita race 3. The snap bean cultivars Macarrão Atibaia and Macarrão Preferido were slightly resistant to Meloidogyne javanica and moderately resistant and susceptible, respectively, to Meloidogyne incognita race 1 . The reactions of the latter cultivars against Meloidogyne incognita race 3 were very resistant and slightly resistant, respectively. The results of these experiments showed that the dry bean cultivars Aporé and Ouro Negro and the snap bean cultivar Macarrão Atibaia have potential to be used in breeding programs for a broader spectrum of root-knot nematode resistances.
\end{abstract}

Snap beans belong to the same botanical species as the dry beans (Phaseolus vulgaris L.) and are among the 10 most widely grown vegetable crops in Brazil, where their production is predominantly based on small farming (Peixoto et al., 2001).

Root-knot nematodes Meloidogyne spp. are considered major pathogens causing yield losses in Phaseolus vulgaris L., especially in regions with prevalent high temperatures, an environmental factor that increases stress and interferes with the expression of plant resistance to nematode parasitism (Pedrosa et al., 2000). These nematodes have a high reproduction rate, reaching large populations in the soils after successive crops of plants considered as good hosts (Campos et al., 2001).

Received for publication 14 Oct. 2009. Accepted for publication 7 Dec. 2009.

We are indebted to Coordenação de Aperfeiçoamento de Pessoal de Nível Superior (Capes), to Fundação de Amparo à Pesquisa do Estado de Minas Gerais (Fapemig), to Conselho Nacional de Desenvolvimento Científico e Tecnológico (CNPq), to Universidade Federal de Lavras (UFLA), to Fundação de Apoio ao Ensino Pesquisa e Extensão (FAEPE), and to HortiAgro Sementes Ltda. for supporting this study.

${ }^{1}$ To whom reprint requests should be addressed; e-mailwrmaluf@dag.ufla.br. widely used by breeding programs (Carneiro et al., 2003; Walber et al., 2003). Despite the great losses recorded on the dry bean and snap bean crops, little effort has been deployed toward obtaining resistant cultivars.

Some studies demonstrate the existence of genetic variability for root-knot nematode resistance among bean accessions (Mullin et al., 1991; Omwega and Roberts, 1992; Silva et al., 2005). Vieira (1964), evaluating 18 dry bean cultivars, found that they presented differential responses to damage caused by $M$. incognita, whereas Freire and Ferraz (1977), evaluating 31 cultivars, found that all of them were susceptible to $M$. incognita. Silva et al. (2005) found significant differences in resistance to $M$. incognita among $\mathrm{F}_{3}$ families derived from a cross between bean cultivars Perola $\times$ Batatinha. Evaluation of root-knot nematode resistance of 16 dry bean cultivars (Moura and Regis, 1987) demonstrated that $18.75 \%$ of them were highly susceptible, $50 \%$ slightly resistant, and $31.25 \%$ moderately resistant to $M$. javanica. For M. incognita, $12.5 \%$ were highly susceptible, $12 \%$ susceptible, $25 \%$ slightly resistant, and $50 \%$ moderately resistant. None of the cultivars were described as resistant, highly resistant, or immune to both nematodes.

Mullin et al. (1991), assessing the reaction of more than 150 lines of dry beans to one or more root nematode Meloidogyne populations (M. incognita race 3; mixed $M$. incognita and M. javanica; M. hapla), collected in Colombia and in the United States, found only 30 lines that were moderately resistant or better. Among those that were highly resistant to the nematodes were A211, Carioca, Manoa Wonder, Nemasnap, and PI313709.

Characterization of the reaction of different cultivars to the infestation by specific Meloidogyne species, races, or isolates is needed to identify resistant genotypes that can be effectively used in breeding programs for root-knot nematode resistance in dry beans and snap beans. The objective of this study was to determine the resistance in dry bean and snap bean cultivars to $M$. incognita races 1 and 3 and M. javanica.

\section{Materials and Methods}

Three separate experiments were conducted in a greenhouse at HortiAgro Sementes Ltda in Ijaci, Minas Gerais, Brazil, from 6 Nov. 2007 through 7 Jan. 2008. Seven snap bean cultivars (Macarrão Atibaia, Macarrão Rasteiro Conquista, Macarrão Rasteiro, Macarrão Trepador, Macarrão Rasteiro Dourado, Macarrão Favorito, and Macarrão Preferido) and three dry bean cultivars (Aporé, Ouro Negro, and Talismã) were evaluated for resistance to $M$. incognita races 1 and 3 and $M$. javanica in separate experiments for each of the root-knot nematode tested. The dry bean cultivars were chosen based on several other preliminary studies that described the cultivars Aporé and Ouro Negro as resistant to the rootknot nematode Meloidogyne incognita and the cultivar Talismã as susceptible to this parasite (Carneiro et al., 2003; Silva et al., 2005). All 
dry bean and snap bean cultivars tested in the experiments are freely available for trial and breeding purposes.

Each of the experiments was set up in a randomized complete block design with four replications with four plants per plot grown in separate pots. Each block included a four-pot plot with tomato (Solanum lycopersicum L.) cultivar Santa Clara known to be susceptible to both $M$. incognita and $M$. javanica to confirm inoculum efficacy and to be a control for the determination of reproduction rates. Three seeds were sown in 3-L plastic pots containing a mixture of soil, sand, and compost (2:1:1 on a volume basis) as substrate, which were thinned to one plant per pot after germination and emergence. Fifteen days after sowing, the substrate was infested with eggs of $M$. incognita races 1 and 3 or $M$. javanica (for each respective experiment). The inocula were obtained from tomato plants of cv. Santa Clara infested with isolates of the nematode species/races under study and maintained in $10-\mathrm{L}$ pots in a greenhouse at the experimental station of HortiAgro Sementes Ltda.

Inoculum was prepared according to Hussey and Barker's (1973) methodology modified by Bonetti and Ferraz (1981). Eggs were counted from a 1-mL aliquot in Peter's chamber (Southey, 1970) with the aid of a stereo microscope. In each experiment, 10,000 eggs ( $5 \mathrm{~mL}$ of a $2000 \mathrm{eggs} / \mathrm{mL}$ suspension) were used per 3-L pot, and that was considered the initial nematode population. The suspension was distributed with a syringe directly onto the substrate in two 3 -cm deep $\times 0.5-\mathrm{cm}$ wide holes placed beside the plant stem.

Forty-five days after inoculation (before completion of the second cycle of nematode reproduction), when intense gall formation and egg masses were noticeable on the tomato plants, the nematode reproduction was evaluated for all genotypes. The plants were removed from the pots, and the roots were gently rinsed to remove any adhered substrate. Subsequently, they were blotted dry and weighed to determine the fresh root mass (in grams). The root system was diced and the eggs were extracted as previously indicated (Bonetti and Ferraz, 1981). The number of eggs in the root system was counted with the aid of a stereo microscope, and the final number of nematode eggs per gram of fresh root was estimated both for bean plants $\left(\mathrm{P}_{\mathrm{b}}\right)$ and susceptible tomato control plants $\left(\mathrm{P}_{\mathrm{t}}\right)$. These values were used to determine the reproduction index (RI) for each individual plant tested. Reproduction indices were determined by dividing the number of eggs per gram of bean roots $\left(\mathrm{P}_{\mathrm{b}}\right)$ of each plant by the mean number of eggs per gram of tomato roots (mean of $\mathrm{P}_{t}$ ). Results were expressed as relative reproduction indices (RRI) relative to the susceptible tomato standard control (assumed as RRI $=100 \%$ ). Analyses of variance were done for each experiment with data transformed by $\sqrt{\mathrm{x}}$ using the statistical package Sisvar (Ferreira, 2003). Mean separation was according to the Scott and Knott (1974) procedure, a less ambiguous method than other commonly used mean sep- aration tests (Tukey, Scheffé, Duncan, and others) that provides for a control of the Type I error.

The degree of resistance of each cultivar to $M$. incognita races 1 and 3 and to $M$. javanica was determined based on the RRI according to the criteria established by Taylor (1967). The resistance degrees were considered as follows: $\mathrm{S}=$ susceptible (normal reproduction) $=$ reproductive index (RRI) of $50 \%$ or more; SLR = slightly resistant $=$ RRI between $25 \%$ and $50 \%$; MoR $=$ moderately resistant $=$ RRI between $10 \%$ and $25 \% ; \mathrm{VR}=$ very resistant $=\mathrm{RRI}$ between $1 \%$ and $10 \%$; HR = highly resistant $=$ RRI between $0 \%$ and $1 \%$; and $\mathrm{I}=$ immune $=$ no reproduction $=\mathrm{RRI}=0 \%$.

\section{Results and Discussion}

The analyses of variance in all three experiments indicated significant differences in nematode resistance among genotypes, confirming the existence of genetic variability for resistance against $M$. javanica and against $M$. incognita races 1 and 3 in dry bean and snap bean cultivars. Differences among the bean cultivars tested were detected by the Scott-Knott test at 5\% with respect to rootknot nematode reproduction (Table 1).

According to the reproduction criterion established by Taylor (1967), the dry bean cultivars Aporé and Talismã were considered as very resistant (VR) against $M$. javanica (Table 1). The dry bean cv. Ouro Negro and the snap beans 'Macarrão Preferido', 'Macarrão Atibaia', and 'Macarrão Trepador' were considered slightly resistant (SLR) to this nematode (Table 1). In contrast, the snap bean cultivars Macarrão Favorito, Macarrão Rasteiro Conquista, Macarrão Rasteiro, and Macarrão Rasteiro Dourado were susceptible (S) to M. javanica (Table 1).

Other authors reported sources of resistance to M. javanica in Phaseolus vulgaris.

Table 1. Relative reproduction index (RRI) of Meloidogyne javanica and Meloidogyne incognita races 1 and 3 and resistance degree (RD) of three dry bean cultivars, seven snap bean cultivars, and the tomato cultivar Santa Clara (standard susceptible control); Ijaci, MG, Brazil; 2008.

\begin{tabular}{|c|c|c|c|c|c|c|c|}
\hline \multirow[b]{3}{*}{ Crop } & \multirow[b]{3}{*}{ Cultivar } & & & \multicolumn{4}{|c|}{ Meloidogyne incognita } \\
\hline & & \multicolumn{2}{|c|}{ Meloidogyne javanica } & \multicolumn{2}{|c|}{ Race 1} & \multicolumn{2}{|c|}{ Race 3} \\
\hline & & $\operatorname{RRI}(\%)^{\mathrm{z}, \mathrm{x}}$ & $\mathrm{RD}^{\mathrm{y}, \mathrm{w}}$ & $\operatorname{RRI}(\%)^{z, x}$ & $\mathrm{RD}^{\mathrm{y}, \mathrm{w}}$ & $\overline{R R I}(\%)^{z, x}$ & $\mathrm{RD}^{\mathrm{y}, \mathrm{w}}$ \\
\hline Tomato & Santa Clara & $100 \mathrm{c}$ & $\mathrm{S}$ & $100 \mathrm{~b}$ & $\mathrm{~S}$ & $100 \mathrm{~b}$ & $\mathrm{~S}$ \\
\hline \multirow[t]{3}{*}{ Dry bean } & Aporé & $3 a$ & VR & $42 \mathrm{a}$ & SLR & $12 \mathrm{a}$ & MoR \\
\hline & Talismã & $9 \mathrm{a}$ & VR & $40 \mathrm{a}$ & SLR & $27 \mathrm{a}$ & SLR \\
\hline & Ouro Negro & $41 \mathrm{~b}$ & SLR & $29 \mathrm{a}$ & SLR & $11 \mathrm{a}$ & MoR \\
\hline \multirow[t]{7}{*}{ Snap bean } & Macarrão Atibaia & $48 \mathrm{~b}$ & SLR & $15 \mathrm{a}$ & MoR & $6 \mathrm{a}$ & VR \\
\hline & Macarrão Preferido & $36 \mathrm{~b}$ & SLR & $65 \mathrm{~b}$ & $\mathrm{~S}$ & $36 \mathrm{a}$ & SLR \\
\hline & Macarrão Trepador & $49 \mathrm{~b}$ & SLR & $52 \mathrm{~b}$ & $\mathrm{~S}$ & $29 \mathrm{a}$ & SLR \\
\hline & Macarrão Favorito & $66 \mathrm{~b}$ & $\mathrm{~S}$ & $32 \mathrm{a}$ & SLR & $15 \mathrm{a}$ & MoR \\
\hline & $\begin{array}{l}\text { Macarrão Rasteiro } \\
\text { Conquista }\end{array}$ & $125 \mathrm{c}$ & $\mathrm{S}$ & $157 \mathrm{c}$ & $\mathrm{S}$ & $146 \mathrm{~b}$ & $\mathrm{~S}$ \\
\hline & Macarrão Rasteiro & $155 \mathrm{c}$ & $\mathrm{S}$ & $151 \mathrm{c}$ & $\mathrm{S}$ & $149 \mathrm{~b}$ & $\mathrm{~S}$ \\
\hline & $\begin{array}{l}\text { Macarrão Rasteiro } \\
\text { Dourado }\end{array}$ & $341 \mathrm{~d}$ & S & $400 \mathrm{~d}$ & $\mathrm{~S}$ & $311 \mathrm{c}$ & $\mathrm{S}$ \\
\hline
\end{tabular}

${ }^{\mathrm{z}} \mathrm{RRI}=$ reproduction index relative to susceptible tomato.

${ }^{y}$ Means followed by the same letter do not differ from each other by the Scott and Knott (1974) test at 5\% probability.

${ }^{\mathrm{x}} \mathrm{RD}=$ resistance degrees, as defined by Taylor (1967).

${ }^{\mathrm{w}} \mathrm{S}=$ susceptible (more than $\left.50 \%\right)$; SLR = slightly resistant $(25 \%$ to $50 \%)$; MoR = moderately resistant $(10 \%$ to $25 \%) ; \mathrm{VR}=$ very resistant $(1 \%$ to $10 \%) ; \mathrm{HR}=$ highly resistant $($ less than $1 \%) ; \mathrm{I}=0 \%=$ immune, according to Taylor (1967).
Perre and dos Santos (2003) reported eight cultivars considered resistant to $M$. javanica and three ('Diamante Negro', 'FT-Nobre', and 'Iapar-80') susceptible (with relative good nematode hosts. Pedrosa et al. (2000) reported only five $M$. javanica resistant genotypes ('A 521', 'A 790', 'L 611002', 'L 634005', and 'L 639012') among 162 tested ceptible dry bean cultivar cone to the susDespite different methodologies deployed for assessment of $M$.javanica resistance, Perre and dos Santos (2003) and Pedrosa et al. species among Phaseolus vulgaris genotypes.

Snap bean cultivar Macarrão Atibaia presented the greatest resistance level against $M$. gnita race 1 and was classified as modercultivars Ouro Negro, Talismã, and Aporé an the snap bean cultivar Macarrão Favorito were considered slightly resistant (SLR) (Taylor, 1967), although the Scott-Knott test did not cultivars and 'Macarrão A tibaia' (Table 1). In contrast, snap bean cultivars Macarrão Trepador, Macarrão Preferido, Macarrão Rasteiro, Macarrão Rasteiro Conquista, and Macarrão 1). In contrast with susce et al. (2000), using the dry bean cultivar IPA9 as a susceptible control, could not identify genotypes with resistance to $M$. incognita race 1 among the 162 accessions tested.

Similar to the $M$. incognita race 1 trial, snap cultivar Macarrão Atibaia presented the race 3 and was clasified against $M$. incognita (Table 1). The dry bean cultivars Ouro Negro and Aporé and the snap bean cultivar Macarrão Favorito were moderately resistant (MoR), whereas dry bean cultivar Talismã and variability for as our present resuls indicate 
snap bean cultivars Macarrão Trepador and Macarrão Preferido were slightly resistant (SLR) by Taylor's (1967) criterion, although their RRIs did not differ significantly from that of 'Macarrão Atibaia' by the Scott-Knott test (Table 1). The snap bean cultivars Macarrão Rasteiro Conquista, Macarrão Rasteiro, and Macarrão Rasteiro Dourado were susceptible (S) to this nematode (Table 1). In contrast with our results, a study by Carneiro et al. (1992) found that all 111 dry bean accessions tested were found to be susceptible to $M$. incognita race 3 . However, their results may not be strictly comparable to our results, because the set of accessions tested, the control dry bean cultivar (Rico 23), and the trait assessed (gall index) were different.

The present study indicated that there is genetic variability for resistance against rootknot nematodes among the Phaseolus vulgaris cultivars of both dry beans and snap beans. The resistance reaction tends to be different, in some genotypes, when challenged with different nematode species or races, a conclusion inferred from Pedrosa et al. (2000). This was the case with dry bean cultivars Aporé and Talismã, which were very resistant to M. javanica, but only slightly resistant to $M$. incognita race 1, whereas their resistance to race 3 of $M$. incognita was moderate and slight, respectively. Among the snap beans, the cultivars Macarrão Atibaia and Macarrão Preferido were slightly resistant to M. javanica, but, when challenged with $M$. incognita race 1 , they were classified as moderately resistant and susceptible, respectively. When race 3 of $M$. incognita was used, their reactions were very resistant and slightly resistant, respectively.

These results indicate that resistance against root-knot nematodes in Phaseolus vulgaris may be controlled by different genes depending on the Meloidogyne species or races considered. Crosses between cultivars with the greatest resistance level for different root-knot nematode species or races should be feasible alternatives to obtain new cultivars with a resistance to a broader range of root-knot nematode species or races. Among the genotypes tested, the snap bean cultivar Macarrão Atibaia appears to be the best source of resistance to $M$. incognita races 1 and 3 according to Taylor's (1967) criterion, whereas the dry bean cultivars Aporé and Talismã are the best sources of resistance $M$. javanica. Attempts to breed new dry bean or snap bean cultivars with resistance to a broad range of root nematode species or races should include crosses with snap bean cultivar Macarrão Atibaia and either dry bean cultivar Aporé or Talismã.

\section{Literature Cited}

Bonetti, J.I.S. and S. Ferraz. 1981. Modificação do método de Hussey \& Barker para extração de ovos de Meloidogyne exigua de raízes de cafeeiro. Fitopatol. Bras. 6:553.

Campos, V.P., J.R. Campos, L.D.C.P. Silva, and M.R. Dutra. 2001. Manejo de nematóides em hortaliças, p. 125-158. In: Silva, L.H.C.P., J.R. Campos, and G.B.A. Nojosa (eds.). Manejo integrado: Doenças e pragas em hortaliças. UFLA, Lavras, Brazil.

Carneiro, G.E.S., M.J. Del Peloso, C.A.F. Oliveira, E. Oliveira, and J.F.V. Silva. 2003. Avaliação da resistência de linhagens de feijoeiro (Phaseolus vulgaris L.) a Meloidogyne javanica. Nematologia Brasileira 27:244-245 Resumos apresentados no XXIV Congresso Brasileiro de Nematologia, Petrolina/PE.

Carneiro, R.G., S. Ferraz, and A.J. Regazzi. 1992. Estudo de mecanismo de resistência a Meloidogyne incognita raça $3 \mathrm{em}$ variedades de feijoeiro. Nematologia Brasileira 16:41-52.

Charchar, J.M., Y. Horino, and A.W. Moita. 1995. Reação de cultivares de feijão vagem em áreas infestadas por Meloidogyne javanica. Horticultura Brasileira 13:77.

Ferreira, D.F. 2003. Programa Sisvar.exe Sistema de Análise de Variância-Versão 4.3. UFLA, Lavras, Brazil.

Freire, F.C.O. and S. Ferraz. 1977. Resistência de cultivares de feijoeiro a Meloidogyne incognita e $M$. javanica e influência da temperatura e exsudatos radiculares. Revista Ceres 24:247260.

Hussey, R.S. and K.R. Barker. 1973. A comparison of methods collecting inocula of Meloidogyne spp. including a new technique. Plant Disease Reporter 57:1025-1028.

Moura, R.M. and E.M.O. Regis. 1987. The effect of Meloidogyne javanica and M. incognita para- sitism of bean (Phaseolus). Nematologia Brasileira 11:215-225.

Mullin, B.A., G.S. Abawi, M.A. Pastor-Corrales, and J.L. Kornegay. 1991. Reactions of selected bean pure lines and accessions to Meloidogyne species. Plant Dis. 75:1212-1216.

Omwega, C.O. and P.A. Roberts. 1992. Inheritance of resistance to Meloidogyne spp. in common bean and the genetic basis of its sensitivity to temperature. Theor. Appl. Genet. 83:720-726.

Pedrosa, E.M.R., R.M. Moura, and E.G. Silva. 2000. Respostas de genótipos de Phaseolus vulgaris à meloidoginose e alguns mecanismos envolvidos na reação. Fitopatol. Bras. 25:190196.

Peixoto, N., E.A. Morais, J.D. Monteiro, and M.D.T. Thung. 2001. Seleção de linhagens de feijão-vagem de crescimento indeterminado para cultivo no estado de Goiás. Horticultura Brasileira 19:85-88.

Perre, J. and M.A. dos Santos. 2003. Reação de cultivares de feijoeiro comum aos fitonematóides de importância primária. In: Congresso Brasileiro de Fitopatologia, 12. Uberlândia. Anais. SBF, 28 (Suplemento). p. 292.

Scott, A.J. and M.A. Knott. 1974. A cluster analysis method for grouping means in the analysis of variance. Biometrics 30:507-512.

Silva, F.B., M.A.P. Ramalho, and A.F.B. de Abreu. 2005. Genetic control of Meloidogyne incognita resistance in common bean. Bean Improvement Cooperative 48:64-65.

Simão, G., M. Homechin, D.C. Santiago, R.T.V. da Silva, and E.R. Ribeiro. 2005. Comportamento de duas cultivares de feijoeiro em relação a Meloidogyne javanica. Ciência Rural 35: 226-270.

Southey, J.F. 1970. Laboratory methods for work with plant and soil nematodes. 5th Ed. Ministry of Agriculture and Food, London, UK.

Taylor, A.L. 1967. Introduction to research on plant nematology. An FAO Guide to Study and Control of the Plant-Parasitic Nematodes. Food and Agricultural Organization of the United Nations, Rome, Italy. PL:CP/5. p. 133.

Vieira, C. 1964. Melhoramento do feijoeiro (Phaseolus vulgaris L.) no estado de Minas Gerais. I. Ensaios comparativos de variedades realizados no período de 1956 a 1961. Experientiae 4:1-68.

Walber, R., F. Juliatti, and M.A. Santos. 2003. Avaliação de acessos de feijoeiro em relação aos nematóides de galhas. In: Congresso Brasileiro de Fitopatologia, 36. Uberlândia/MG. Fitopatol. Bras. 28:293-294. 